\title{
Oxidative stress caused by a low concentration of hydrogen peroxide induces senescence-like changes in mouse gingival fibroblasts
}

\author{
TAMOTSU KIYOSHIMA ${ }^{1}$, NORIO ENOKI ${ }^{2}$, IEYOSHI KOBAYASHI ${ }^{1}$, TAKAKO SAKAI ${ }^{3}$, \\ KENGO NAGATA $^{1}$, HIROKO WADA ${ }^{1}$, HIROAKI FUJIWARA ${ }^{1}$, \\ YUKIKO OOKUMA $^{1,4}$ and HIDETAKA SAKAI ${ }^{1}$ \\ ${ }^{1}$ Laboratory of Oral Pathology and Medicine, Faculty of Dental Science, Kyushu University, Fukuoka 812-8582; \\ ${ }^{2}$ Department of Morphological Biology, Pathology Section, Fukuoka Dental College, Sawara-ku, Fukuoka 814-0193; \\ Departments of ${ }^{3}$ Fixed Prosthodontics and ${ }^{4}$ Pediatric Dentistry, Faculty of Dental Science, \\ Kyushu University, Fukuoka 812-8582, Japan
}

Received April 22, 2012; Accepted June 12, 2012

DOI: $10.3892 /$ ijmm.2012.1102

\begin{abstract}
Periodontal tissue deteriorates under persistent oxidative stress induced by inflammatory reactions in the microflora of the oral cavity. This study aimed to evaluate the cellular properties of mouse gingival fibroblasts (MGFs) in the presence of oxidative stress. MGFs from 10-, 30- and 52 -week-old mice were used to evaluate the changes in the cellular properties with aging. The study investigated the effects of oxidative stress on the cellular properties of MGFs from 10-week-old mice. The expression of p53, p21 and murine double minute $2(\mathrm{Mdm} 2)$ in the MGFs in response to oxidative stress was also examined. By day 8 , the number of MGFs increased in culture. However, the increase was markedly lower in MGFs derived from aged mice. Oxidative stress due to hydrogen peroxide $\left(\mathrm{H}_{2} \mathrm{O}_{2}\right)$-induced morphological changes characterized by a round shape with enlarged nuclei and expanded cytoplasm. The cell number of MGFs was decreased subsequent to treatment with $50 \mu \mathrm{M}$ or a higher concentration of $\mathrm{H}_{2} \mathrm{O}_{2}$. MGFs treated with $\mathrm{H}_{2} \mathrm{O}_{2}$ at $20 \mu \mathrm{M}$ showed a similar cell growth curve as the one seen in 52-week-old mice. Phosphorylated p53 protein was increased in MGFs subsequent to treatment with $20 \mu \mathrm{M} \mathrm{H}_{2} \mathrm{O}_{2}$, along with an upregulated transcription of p21 and Mdm2 mRNAs. These results suggest that treatment with a lower concentration of $\mathrm{H}_{2} \mathrm{O}_{2}$ in MGFs induces cell cycle arrest, resulting in stress-induced premature senescence, possibly correlated with the development of periodontal diseases.
\end{abstract}

Correspondence to: Professor Hidetaka Sakai, Laboratory of Oral Pathology and Medicine, Faculty of Dental Science, Kyushu University, 3-1-1 Maidashi, Higashi-ku, Fukuoka 812-8582, Japan

E-mail: hsakaiop@dent.kyushu-u.ac.jp

Key words: stress, gingival fibroblast, cell senescence

\section{Introduction}

Aging is a physiological phenomenon, which commonly occurs in various organs and tissues (1). Age-dependent morphological and cell kinetic changes in the organs and tissues are associated with the development of various diseases in the elderly. A decline in the function of organs and tissues is a normal phenomenon associated with aging, and is also considered to reduce the quality of life (1).

Several reports are available regarding the relationship between aging and periodontitis (2-5). The aging of the periodontal tissue is involved in the development of periodontitis in elderly individuals (6).

The age-dependent morphological and cell kinetic changes of the gingival tissue were delineated, using both the 5-bromo-2'-deoxyuridine (BrdU) incorporation and the terminal deoxynucleotidyl transferase-mediated deoxyuridine-5'-triphosphate (dUTP)-biotin nick end-labeling (TUNEL) methods $(7,8)$. Those studies demonstrated that with aging there is a significant apoptosis-induced decrease in the cellular component of the subepithelial connective tissue of both the gingival and junctional epithelial layer. Furthermore, an age-dependent increase in the number of TUNEL-positive cells occurred only in the subepithelial connective tissue, although gingival tissue, buccal mucosa, tongue dorsal, ventral mucosae and skin have similar histological structures (9).

Oxidative stress is one of the most important causative factors for the induction of cell apoptosis $(10,11)$. Incubationinduced subcytotoxic stress with potentially harmful molecules, such as hydrogen peroxide $\left(\mathrm{H}_{2} \mathrm{O}_{2}\right)$ brought the cells into a state similar to senescence, termed stress-induced premature senescence (SIPS) (12-14). Therefore, in this study, the agedependent changes in the cell number in cultured mouse gingival fibroblasts (MGFs), as well as the changes in the biological behavior subsequent to treatment with $\mathrm{H}_{2} \mathrm{O}_{2}$ in the MGFs were investigated. 


\section{Materials and methods}

Animals. BALB/c mice were used to investigate the age-related changes in the cell number in MGFs in 10-, 15-, 30- and 52 -week-old mice ( $\mathrm{n}=3$ per group). In addition, 10 -weekold mice were used for the oxidative stress experiment $(\mathrm{n}=3$ per group). The animals were bred in a strictly monitored air-conditioned clean room and were fed standard laboratory pellets and water ad libitum. The experiment was performed according to the guidelines of the Animal Center at the Kyushu University.

Gingival fibroblast cultures. The animals were sacrificed using an excessive amount of ether. The gingival tissues were removed, immediately washed in phosphate-buffered saline (PBS) with gentamicin $(10 \mu \mathrm{g} / \mathrm{ml}$; Invitrogen, Carlsbad, CA, USA) and transferred into a culture dish. The gingival fibroblasts were grown in $\alpha$-MEM, supplemented with $10 \%$ fetal bovine serum (FBS), $100 \mathrm{IU} / \mathrm{ml}$ penicillin and $100 \mu \mathrm{g} /$ $\mathrm{ml}$ streptomycin in a humidified atmosphere with $5 \% \mathrm{CO}_{2}$ at $37^{\circ} \mathrm{C}$. The medium was changed every other day. The cells were grown to semi-confluence, harvested by trypsinization at $37^{\circ} \mathrm{C}$ for $5 \mathrm{~min}$, then subcultivated with culture medium in a new dish. The experiments were performed using earlypassage fibroblasts before the fourth passage.

Cell growth assay. MGFs (1.0x10 $10^{4}$ cells/well) were seeded onto 12 -well plates in the $\alpha$-MEM with serum. The cell numbers in three-wells of each group were counted chronologically at 2 , 4, 6 and 8 days after cultivation. The results were expressed as the mean \pm SD.

Oxidative stress. At $48 \mathrm{~h}$ after seeding, MGFs were exposed to oxidative stress for $2 \mathrm{~h}$. Various concentrations of $\mathrm{H}_{2} \mathrm{O}_{2}$ were diluted in $\alpha$-MEM with $10 \%$ FBS. Subsequent to treatment with $\mathrm{H}_{2} \mathrm{O}_{2}$, the cultures were rinsed twice with PBS and incubated in $\alpha$-MEM with $10 \%$ FBS. Some samples were stained with nuclear fast red to observe cellular and nuclear morphological changes in the MGFs after the oxidative stress.

Senescence-associated $\beta$-galactosidase (SA- $\beta$-Gal) activity. MGFs were cultured for 14 days subsequent to treatment with $\mathrm{H}_{2} \mathrm{O}_{2}$. The SA- $\beta$-Gal-positive cell ratios were determined in three wells, using a senescence detection kit, according to the manufacturer's instructions. To avoid any non-specific staining due to confluence, SA- $\beta$-Gal cytochemical staining was performed on non-confluent cells.

Semi-quantitative reverse transcriptase polymerase chain reaction ( $R T$-PCR). A semi-quantitative RT-PCR analysis was carried out. Total-RNA extracted from cultured mouse gingival cells was isolated using the SV total-RNA isolation system, according to the manufacturer's instructions. cDNA was generated from isolated total-RNA by reverse transcription (RT) with SuperScript III and subjected to PCR amplification with the specific primer sets (Table I). Glyceraldehyde-3-phosphate dehydrogenase (GAPDH) was used as the internal RNA control for the comparison of RNA levels in each sample. The PCR products were separated by electrophoresis on agarose gels and then stained with ethidium bromide.
Table I. Primer sets used for semi-quantitative RT-PCR.

\begin{tabular}{ll}
\hline Target & \multicolumn{1}{c}{ Sequence } \\
\hline p53 & F: 5'-GGA AAT TTG TAT CCC GAG TAT CTG-3' \\
& R: 5'-GTC TTC CAG TGT GAT GAT GGT AA-3' \\
p21 & F: 5'-TGT CCA ATC CTG GTG ATG TC-3' \\
& R: 5'-TCT CTT GCA GAA GAC CAA TCT G-3' \\
Mdm2 & F: 5'-CCA GGC CAA TGT GCA ATA C-3' \\
& R: 5'-GTG AGC AGG TCA GCT AGT TGA A-3' \\
GAPDH & F: 5'-ACC ACA GTC CAT GCC ATC AC-3' \\
& R: 5'-TCC ACC ACC CTG TTG CTG TA-3' \\
\hline
\end{tabular}

F, forward; R, reverse; Mdm2, murine double minute 2; GAPDH, glyceraldehyde-3-phosphate dehydrogenase.

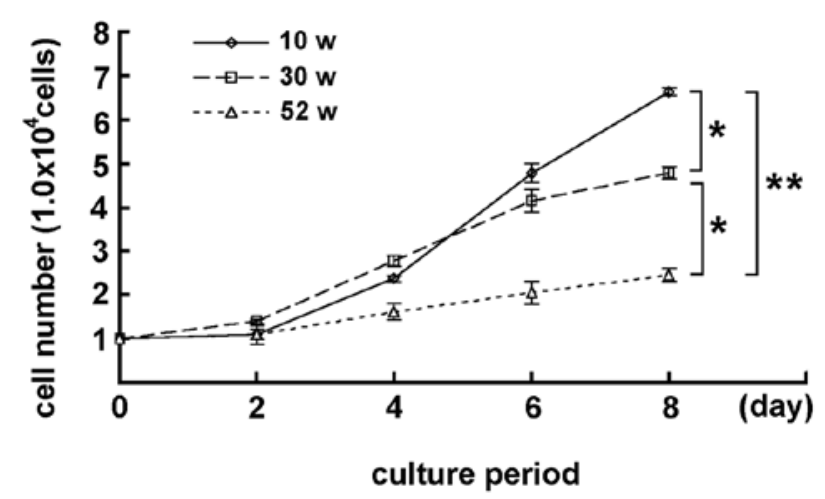

Figure 1. Chronological change of the number of MGFs isolated from 10-, 30- and 52-week-old mice. The cell growth curve of MGFs at each culture day was different at each age. Significant differences in the cell number at day 8 of culturing were detected between 10 - and 30 -week-old, and 30 - and 52 -week-old mice $\left({ }^{*} \mathrm{P}<0.05\right)$. A significant difference was also observed between 10 - and 52 -week-old mice $\left({ }^{* *} \mathrm{P}<0.01\right)$. The cell growth curves of the MGFs are different in the 10-, 30- and 52-week-old mice.

Immunoblotting for the 553 phosphorylation status. An immunoblot analysis for $\mathrm{p} 53$ was carried out using the proteins isolated from the cultured MGFs after the treatment with $20 \mu \mathrm{M}$ $\mathrm{H}_{2} \mathrm{O}_{2}$ for $2 \mathrm{~h}$. These cells were lysed in RIPA buffer $(50 \mathrm{mM}$ Tris pH 8.0, $150 \mathrm{mM} \mathrm{NaCl}, 1 \%$ Triton X-100, 1 mM EDTA $\mathrm{pH} 8.0,0.1 \%$ SDS), supplemented with protease inhibitor cocktail $(50 \mu \mathrm{M})$, lactacystin $(20 \mu \mathrm{M})$ and PMSF. The protein samples were separated using SDS-PAGE, transferred to an Immun-Blot ${ }^{\circledR}$ PVDF Membrane, and immunoblotted with anti-p53 antibody (sc-6243; Santa Cruz Biotechnology, Inc., Santa Cruz, CA, USA) and anti-phospho-p53 antibody (S15; R\&D Systems, Inc., Minneapolis, MN, USA). The membrane was incubated with suitable secondary antibody conjugated with horseradish peroxidase. Immunoreactive proteins were visualized using an ECL detection system. Any emitted light was detected using a cooled CCD-camera (LAS-1000; Fujifilm, Tokyo, Japan).

Statistical analysis. The experiments were repeated three times for the independent MGF samples. A statistical analysis was 

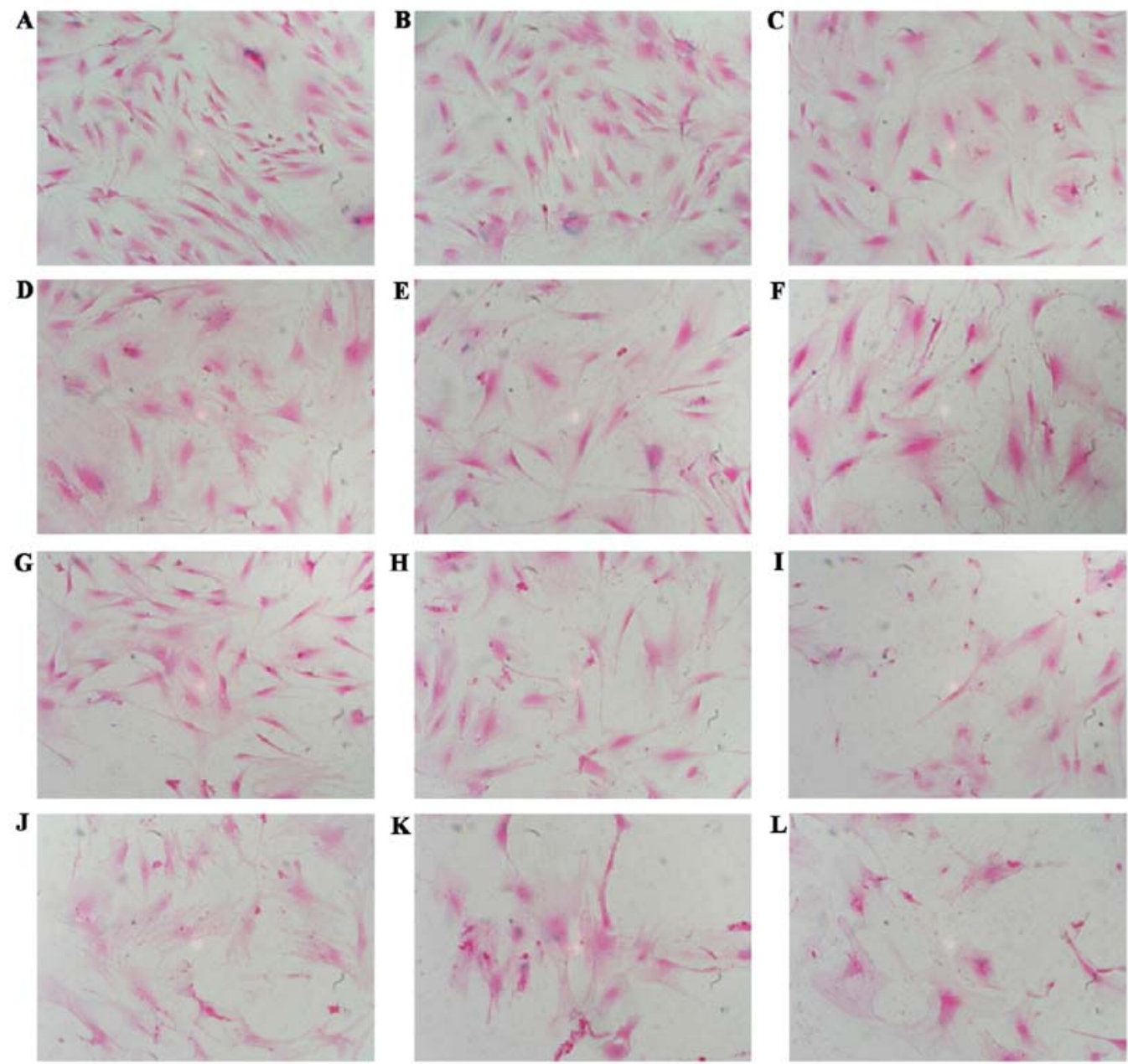

Figure 2. Morphological change in MGFs subsequent to treatment with $\mathrm{H}_{2} \mathrm{O}_{2}$ is shown. MGFs were (A) non-treated and (B-L) treated with various concentrations of $\mathrm{H}_{2} \mathrm{O}_{2} . \mathrm{H}_{2} \mathrm{O}_{2}$-treated cells showed a round shape with enlarged nuclei and expanded cytoplasm. A decrease in the cell number was evident in the $\mathrm{H}_{2} \mathrm{O}_{2}$-treated samples. (A) Non-treated, (B) $50 \mu \mathrm{M}$, (C) $100 \mu \mathrm{M}$, (D) $150 \mu \mathrm{M}$, (E) $200 \mu \mathrm{M}$, (F) $250 \mu \mathrm{M}$, (G) $300 \mu \mathrm{M}$, (H) $350 \mu \mathrm{M}$, (I) $400 \mu \mathrm{M}$, (J) $450 \mu \mathrm{M}$, (K) $500 \mu \mathrm{M}$ and (L) $550 \mu \mathrm{M}$.

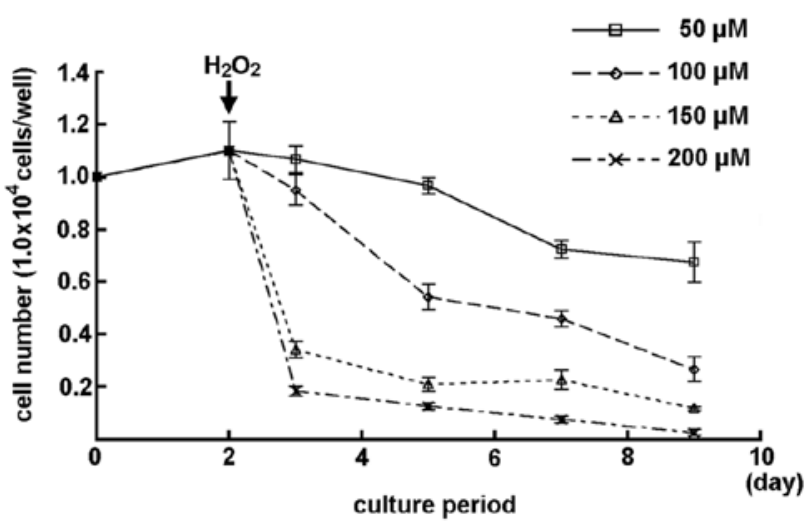

Figure 3. Effect of $\mathrm{H}_{2} \mathrm{O}_{2}$ treatment on the cell growth of MGFs. A slight decrease in the cell number was observed in the MGFs subsequent to treatment with $50 \mu \mathrm{M} \mathrm{H}_{2} \mathrm{O}_{2}$. Additionally, a marked decrease in the cell number in MGFs is detected subsequent to treatment with $100 \mu \mathrm{M}$ or higher concentrations of $\mathrm{H}_{2} \mathrm{O}_{2}$.

performed combining one-way ANOVA with the Tukey-Kramer comparison test or Student's t-test. P-values $<0.05$ or 0.01 were considered to indicate statistically significant differences.

\section{Results}

Age-dependent change in the cell number in MGFs. MGFs isolated from 10-, 30- and 52-week-old mice were cultured for 2, 4, 6 and 8 days. Although the MGFs showed cell proliferation while cultured, the number of MGFs was different on each culture day, depending on the age of the mouse, from which the sample was derived. Marked differences were detected in the cell number in 10- and 30-week-old, and 30- and 52-weekold mice $(\mathrm{P}<0.05)$ at day 8 of the culturing. A statistically significant difference was also observed between 10 - and 52-week-old mice $(\mathrm{P}<0.01)$, indicating that the increase in the number of cultured MGFs was apparently lower in samples from older mice (Fig. 1). In the subsequent oxidative stress experiments MGFs derived from 10-week-old mice were used.

Effects of oxidative stress on the morphological change in MGFs subsequent to $\mathrm{H}_{2} \mathrm{O}_{2}$ treatment. MGFs were treated with various concentrations of $\mathrm{H}_{2} \mathrm{O}_{2}$. The MGFs were observed under the microscope after $24 \mathrm{~h}$. Non-treated MGFs showed a fibroblastic spindle shape. As seen in previously-reported SIPS-like changes, the $\mathrm{H}_{2} \mathrm{O}_{2}$-treated cells had a round shape with enlarged nucleus and expanded cytoplasm (Fig. 2) $(13,14)$. 


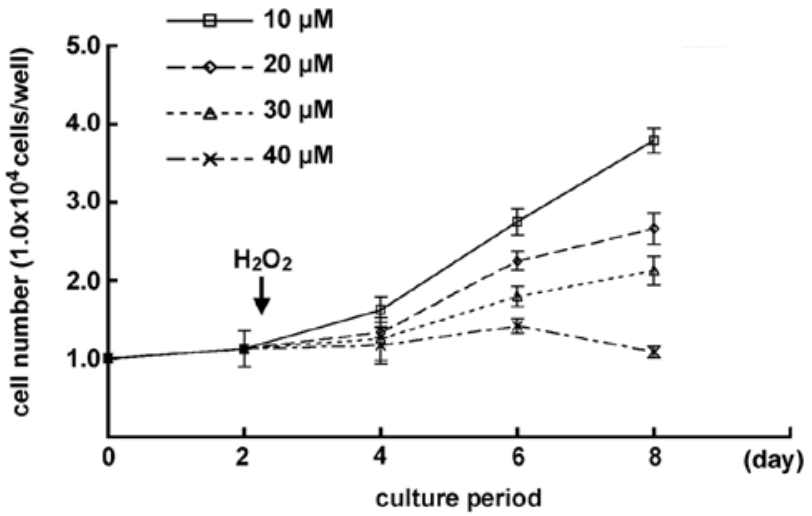

Figure 4. Effect of lower concentrations of $\mathrm{H}_{2} \mathrm{O}_{2}$ on the cell growth in MGFs. A chronological increase in the cell number was demonstrated in samples with 10,20 and $30 \mu \mathrm{M} \mathrm{H}_{2} \mathrm{O}_{2}$. No significant change was seen in the cell growth in the sample after $40 \mu \mathrm{M} \mathrm{H}_{2} \mathrm{O}_{2}$-treatment.

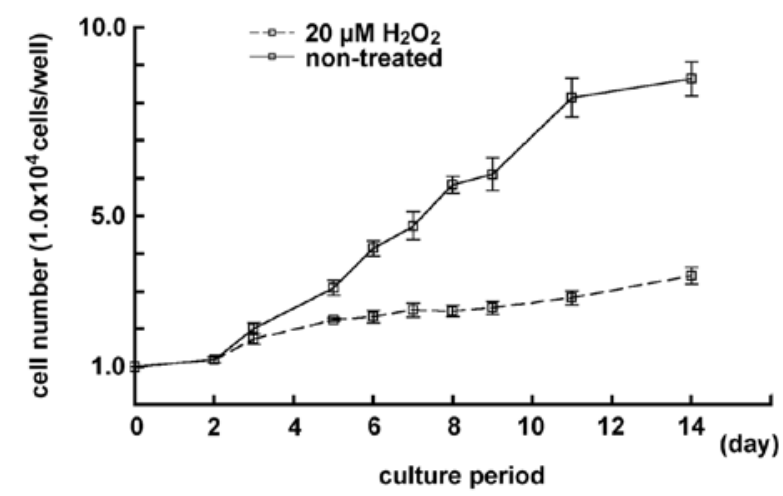

Figure 5. Effect of $20 \mu \mathrm{M}$ concentration of $\mathrm{H}_{2} \mathrm{O}_{2}$ treatment on the cell growth in MGFs in a prolonged culturing. A slightly increased ratio in the cell number of MGFs treated with $\mathrm{H}_{2} \mathrm{O}_{2}$, was observed after 8 days of culturing. The growth curve is similar to the one observed in samples from 52-week-old mice.

The detachment of the cells from the culture dish also increased in an $\mathrm{H}_{2} \mathrm{O}_{2}$ concentration-dependent manner, indicating that cell death occurred in the MGFs.

Effects of oxidative stress on the cell number of MGFs subsequent to $\mathrm{H}_{2} \mathrm{O}_{2}$ treatment. The number of MGFs subsequent to treatment with various concentrations of $\mathrm{H}_{2} \mathrm{O}_{2}$ is shown in Fig. 3. A slight decrease in the cell number was observed in the MGFs treated with $50 \mu \mathrm{M} \mathrm{H}_{2} \mathrm{O}_{2}$. A marked decrease in the cell number of MGFs was detected subsequent to treatment with $100 \mu \mathrm{M}$ or higher concentrations of $\mathrm{H}_{2} \mathrm{O}_{2}$ (Fig. 3).

Effect of lower concentrations of $\mathrm{H}_{2} \mathrm{O}_{2}$ on the cell growth in $M G F s$. The effects of low $\mathrm{H}_{2} \mathrm{O}_{2}$ concentrations on the MGFs were examined, since the cell number of MGFs decreased gradually when treated with $50 \mu \mathrm{M} \mathrm{H}_{2} \mathrm{O}_{2}$. A chronological increase in the cell number was demonstrated in samples with 10, 20 and $30 \mu \mathrm{M} \mathrm{H}_{2} \mathrm{O}_{2}$-treatment. MGFs treated with $20 \mu \mathrm{M}$ $\mathrm{H}_{2} \mathrm{O}_{2}$ showed a chronological cell growth curve, similar to the one seen in the 52-week-old mice. By contrast, no significant change was detected in the cell number of the samples subsequent to treatment with $40 \mu \mathrm{M} \mathrm{H}_{2} \mathrm{O}_{2}$ by day 6 of culturing, while a decreased number of cells was observed at day 8 .

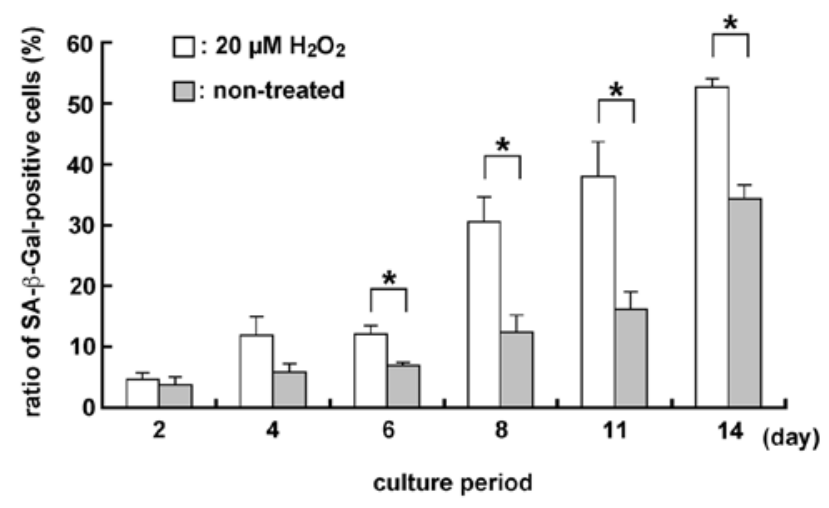

Figure 6. Detection of SA- $\beta$-Gal in the MGFs using $20 \mu \mathrm{M} \mathrm{H}_{2} \mathrm{O}_{2}$. Two days after the treatment, the ratio of SA- $\beta$-Gal-positive cells was larger in $\mathrm{H}_{2} \mathrm{O}_{2}$-treated samples than that in non-treated samples. Significant differences in the number of SA- $\beta$-Gal-positive cells were observed between the $20 \mu \mathrm{M} \mathrm{H}_{2} \mathrm{O}_{2}$-treated and non-treated samples cultured at $6,8,11$ and 14 days of culture $\left({ }^{*} \mathrm{P}<0.05\right)$.

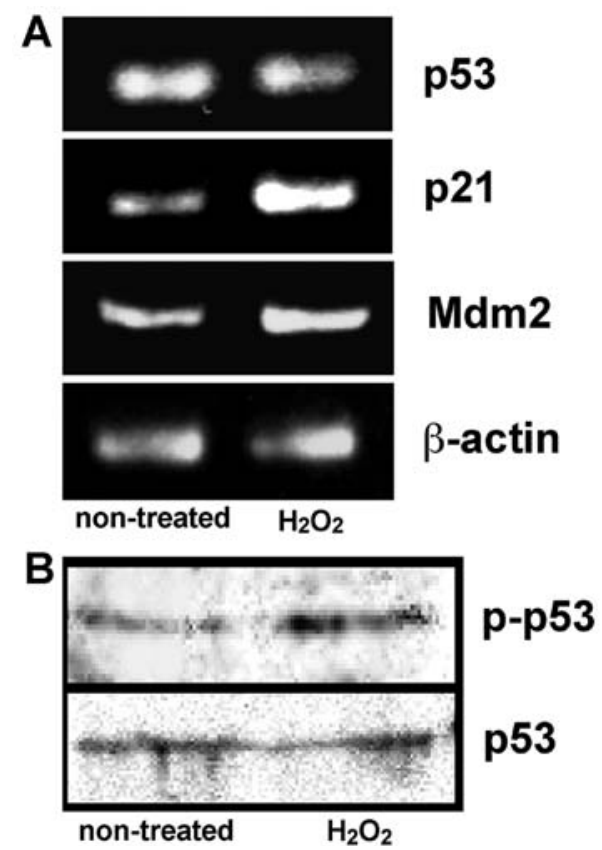

Figure 7. Expression of p53,p21 and Mdm2 mRNA, and the phosphorylation of p53 protein in the culture MGFs under oxidative stress. No significant change in either (A) mRNA or (B) protein expression of p53 was detected in the cultured MGFs treated with $20 \mu \mathrm{M} \mathrm{H}_{2} \mathrm{O}_{2}$. (B) An increased expression of phosphorylated p53 protein was observed in the sample treated with $20 \mu \mathrm{M} \mathrm{H}_{2} \mathrm{O}_{2}$. (A) An increased expression of p21 and Mdm2 mRNAs was also demonstrated in the same sample.

Statistically significant differences were demonstrated in each sample at day 8 of culturing $(\mathrm{P}<0.05)($ Fig. 4$)$.

Effect of $20 \mu \mathrm{M}$ concentration of $\mathrm{H}_{2} \mathrm{O}_{2}$ treatment on the cell growth in MGFs in a prolonged culturing. The cell number in the samples treated with $20 \mu \mathrm{M} \mathrm{H}_{2} \mathrm{O}_{2}$ was examined and compared with the cell number in the non-treated samples, for a period prolonged by 14 days. After 8 days of culturing, the cell number in samples treated with a lower concentration of $\mathrm{H}_{2} \mathrm{O}_{2}$ decreased in the cultured MGFs, and a low cell number increase-ratio was observed. There was a notable difference between the non-treated and the treated samples $(\mathrm{P}<0.05)$ 
(Fig. 5). Furthermore, $\mathrm{H}_{2} \mathrm{O}_{2}$-treated cells had a round shape with enlarged nucleus and expanded cytoplasm, as observed in the senescent fibroblasts. Therefore, MGFs treated with $20 \mu \mathrm{M}$ $\mathrm{H}_{2} \mathrm{O}_{2}$ seemed to mimic the age-dependent decrease of the proliferative activity in the 52-week-old mice.

Detection of SA- $\beta$-Gal in the MGFs using a $20 \mu \mathrm{M} \mathrm{H}_{2} \mathrm{O}_{2}$ treatment. The ratio of SA- $\beta$-Gal (a senescence marker)-positive cells was examined in $\mathrm{H}_{2} \mathrm{O}_{2}$-treated and non-treated samples, since oxidative stress after $\mathrm{H}_{2} \mathrm{O}_{2}$ treatment induced senescence-like morphological and functional changes. Two days after the treatment, the ratio of SA- $\beta$-Gal-positive cells was higher in $\mathrm{H}_{2} \mathrm{O}_{2}$-treated compared to non-treated samples (Fig. 6). Significant differences were noted in the number of SA- $\beta$-Gal-positive cells in $20 \mu \mathrm{M} \mathrm{H}_{2} \mathrm{O}_{2}$-treated and nontreated samples $(\mathrm{P}<0.05)$, subsequent to culture for $6,8,11$ and 14 days.

Expression of p53,p21 and Mdm2 mRNA, and the phosphorylation of p53 protein in the culture MGFs. Oxidative stress induced senescence-like changes in the MGFs, and therefore the expression of p53 having the potential to initiate cell cycle arrest or cell death $(15,16)$ was further examined. In addition, we examined the expression of p53 downstream genes, cyclin-dependent kinase inhibitor p21 and Mdm2 (17) was examined. The phosphorylated p53 protein was detected using an antibody specifically recognizing human, monkey and rat p53 phosphorylated at the serine-15 and the comparable phosphorylated site in mouse p53 (serine-18). By contrast, unphosphorylated p53 is not detected by the antibody. No significant change regarding the mRNA and protein expression of p53 was detected between the non-treated MGFs and MGFs treated with $20 \mu \mathrm{M} \mathrm{H}_{2} \mathrm{O}_{2}$, whereas an increased expression of phosphorylated p53 protein was observed in the samples treated with $20 \mu \mathrm{M} \mathrm{H}_{2} \mathrm{O}_{2}$. An increased expression of $\mathrm{p} 21$ mRNA was demonstrated in the same sample, thus indicating the induction of increased $\mathrm{p} 21$ expression by phosphorylated p53 protein. The $\mathrm{Mdm} 2 \mathrm{mRNA}$ was also increased in the cultured MGFs treated with $20 \mu \mathrm{M} \mathrm{H}_{2} \mathrm{O}_{2}$ (Fig. 7).

\section{Discussion}

The present study demonstrated that oxidative stress generated by treatment with a lower concentration of $\mathrm{H}_{2} \mathrm{O}_{2}$ induced a decrease in the cell number in the cultured MGFs with an increased ratio of SA- $\beta$-Gal-positive cells, a marker of cellular senescence. Oxidative stress generated by externally added $\mathrm{H}_{2} \mathrm{O}_{2}$ induces SIPS in variety of cell types $(13,14,18)$. This study demonstrated, for the first time, that SIPS in gingival fibroblasts was induced by a lower-concentration $\mathrm{H}_{2} \mathrm{O}_{2}$-treatment than previously reported. Previous reports have proven a low concentration of $\mathrm{H}_{2} \mathrm{O}_{2}$ treatment to induce a higher proliferative activity in human dorsal fibroblasts, rabbit lens epithelial cells, baby hamster kidney fibroblasts and embryonic Chinese hamster ovary fibroblasts (19-21). Therefore, it is reasonable to assume that the gingival fibroblast is more sensitive to $\mathrm{H}_{2} \mathrm{O}_{2}$ oxidative stress.

Oxidative stress is one of the most important causative factors for the induction of pathological states, including periodontitis (22-26). Periodontal tissue tends to deteriorate under persistent oxidative stress induced by inflammatory reactions in the microflora of the oral cavity (27). A previous report demonstrated that gingival fibroblast and dorsal fibroblast had different cellular properties, such as the expression of integrin and extracellular matrix receptors. Consequently, experiments using dorsal fibroblasts are not necessarily valid for oral tissues as well (28). These different cellular properties appear to be correlated with higher sensitivity to oxidative stress, thus resulting in the induction of SIPS.

The p53 gene expression was examined since gingival fibroblasts appeared to be more sensitive to oxidative stress. p53 activation is closely correlated with cell cycle arrest and apoptosis when cells deteriorate due to pathogenic stress. There was no change in the level of p53 mRNA and protein expression shown by the semi-quantitative RT-PCR analysis and western blotting, respectively. However, western blotting demonstrated an increase of phosphorylated p53 protein. Therefore, an increased p21 expression level, suppressing the CDK4- and CDK6-activation, is considered to be induced by the increase of phosphorylated p53 protein, resulting in a decrease of cell number in the MGFs treated with a lower concentration of $\mathrm{H}_{2} \mathrm{O}_{2}$. The Mdm2 expression was also activated at the transcription level. These results suggest that Mdm2 functions as a negative feedback regulator to maintain p53 at a low level under oxidative stress, since the major function of Mdm2 is to interact with p53 and thereby induce the ubiquitination and degradation of p53 (29).

In this study, $\mathrm{H}_{2} \mathrm{O}_{2}$-induced oxidative stress generated an increase in the phosphorylated p53 protein-level at serine-18 in the MGFs. The phosphorylation at this site in mouse p53 is comparable to that of human p53 at serine-15. Phosphorylation of human p53 at serine-15 has a significant role in its reduced interaction with the $\mathrm{Mdm} 2$, its negative regulator, and is involved in the impairment of the Mdm2 function by inhibiting p53-dependent transactivation (30). Therefore, the serine-18 of mouse p53 protein may be one of the critical phosphorylation sites that lead to cell cycle arrest and SIPS under oxidative stress. However, the $\mathrm{H}_{2} \mathrm{O}_{2}$-mediated protein kinases involved in p53 phosphorylation remain unknown. Nevertheless, these results do not exclude the possibility that phosphorylation at other sites on p53 may be associated with the occurrence of these phenomena.

Therefore, gingival fibroblasts are more sensitive to oxidative stress, resulting in cell cycle arrest due to an increase of phosphorylated p53 protein. This characteristic of the gingival fibroblasts may be associated with the marked agedependent decrease of cellular components in the periodontal tissue described in previous studies (7-9), as well as with the development of periodontal diseases. In order to develop new preventive methods against various periodontal diseases, additional investigations regarding the molecular interactions within the gingival fibroblasts in association with oxidative stress are required.

\section{Acknowledgements}

This study was funded in part by Grant-in-Aid from the Ministry of Education, Culture, Sports, Science and Technology of Japan nos. 20390466 and 23659880 to H.S. and no. 23659859 to T.K. 


\section{References}

1. Joaquin AM and Gollapudi S: Functional decline in aging and disease: a role for apoptosis. J Am Geriatr Soc 49: 1234-1240, 2001.

2. van der Velden U: The onset age of periodontal destruction. J Clin Periodontol 18: 380-383, 1991.

3. Papapanou PN, Lindhe J, Sterrett JD and Eneroth L: Considerations on the contribution of aging to loss of periodontal tissue support. J Clin Periodontol 18: 611-615, 1991.

4. Burt BA: Epidemiology of dental diseases in the elderly. Clin Geriatr Med 8: 447-459, 1992.

5. Burt BA: Periodontitis and aging: reviewing recent evidence. J Am Dent Assoc 125: 273-279, 1994.

6. Okamura H, Yamaguchi M and Abiko Y: Enhancement of lipopolysaccharide-stimulated PGE2 and IL-1beta production in gingival fibroblast cells from old rats. Exp Gerontol 34: 379-392, 1999.

7. Sakai T, Ohsaki Y, Kido M, Goto M, Terada Y and Sakai H: The distribution of fibronectin and laminin in the murine periodontal membrane, indicating possible functional roles in the apical migration of the junctional epithelium. Arch Oral Biol 41: 885-891, 1996.

8. Sakai T, Kiyoshima T, Kobayashi I, Moroi R, Ibuki T, Nagadome M, Terada Y and Sakai H: Age-dependent changes in the distribution of BrdU- and TUNEL-positive cells in the murine gingival tissue. J Periodontol 70: 973-981, 1999.

9. Enoki N, Kiyoshima T, Sakai T, Kobayashi I, Takahashi K, Terada Y and Sakai H: Age-dependent changes in cell proliferation and cell death in the periodontal tissue and the submandibular gland in mice: a comparison with other tissues and organs. J Mol Histol 38: 321-332, 2007.

10. Holbrook NJ and Ikeyama S: Age-related decline in cellular response to oxidative stress: links to growth factor signaling pathways with common defects. Biochem Pharmacol 64 : 999-1005, 2002.

11. Miyoshi N, Oubrahim H, Chock PB and Stadtman ER Age-dependent cell death and the role of ATP in hydrogen peroxide-induced apoptosis and necrosis. Proc Natl Acad Sci USA 103: 1727-1731, 2006.

12. Toussaint O, Dumont P, Dierick JF, Pascal T, Frippiat C, Chainiaux F, Magalhaes JP, Eliaers F and Remacle J: Stressinduced premature senescence as alternative toxicological method for testing the long-term effects of molecules under development in the industry. Biogerontology 1: 179-183, 2000.

13. Frippiat C, Chen QM, Zdanov S, Magalhaes JP, Remacle J and Toussaint O: Subcytotoxic $\mathrm{H}_{2} \mathrm{O}_{2}$ stress triggers a release of transforming growth factor-beta 1 , which induces biomarkers of cellular senescence of human diploid fibroblasts. J Biol Chem 276: 2531-2537, 2001.
14. Frippiat C, Dewelle J, Remacle J and Toussaint O: Signal transduction in $\mathrm{H}_{2} \mathrm{O}_{2}$-induced senescence-like phenotype in human diploid fibroblasts. Free Radic Biol Med 33: 1334-1346, 2002.

15. Vousden KH: p53: death star. Cell 103: 691-694, 2000.

16. Haupt S, Berger M, Goldberg Z and Haupt Y: Apoptosis - the $\mathrm{p} 53$ network. J Cell Sci 116: 4077-4085, 2003.

17. Barak Y, Juven T, Haffner R and Oren M: Mdm2 expression is induced by wild type p53 activity. EMBO J 12: 461-468, 1993.

18. Dimri GP, Lee X, Basile G, Acosta M, Scott G, Roskelley C, Medrano EE, Linskens M, Rubelj I, Pereira-Smith O, et al: A biomarker that identifies senescent human cells in culture and in aging skin in vivo. Proc Natl Acad Sci USA 92: 9363-9367, 1995.

19. Burdon RH, Alliangana D and Gill V: Hydrogen peroxide and the proliferation of BHK-21 cells. Free Radic Res 23: 471-486, 1995.

20. Burdon RH, Gill V and Alliangana D: Hydrogen peroxide in relation to proliferation and apoptosis in BHK-21 hamster fibroblasts. Free Radic Res 24: 81-93, 1996.

21. Wiese AG, Pacifici RE and Davies KJ: Transient adaptation of oxidative stress in mammalian cells. Arch Biochem Biophys 318: 231-240, 1995.

22. Kimura S, Yonemura $\mathrm{T}$ and Kaya $\mathrm{H}$ : Increased oxidative product formation by peripheral blood polymorphonuclear leukocytes in human periodontal diseases. J Periodontal Res 28: 197-203, 1993.

23. Weiss SJ: Tissue destruction by neutrophils. N Engl J Med 320: 365-367, 1989.

24. Guarnieri C, Zucchelli G, Bernardi F, Scheda M, Valentini AF and Calandriello M: Enhanced superoxide production with no change of the antioxidant activity in gingival fluid of patients with chronic adult periodontitis. Free Radic Res Commun 15: 11-16, 1991.

25. Tsai CC, Ho YP and Chen CC: Levels of interleukin-1 beta and interleukin-8 in gingival crevicular fluids in adult periodontitis. J Periodontol 66: 852-859, 1995.

26. Ren Y, Maltha JC, Van't Hof MA, Von Den Hoff JW, KuijpersJagtman AM and Zhang D: Cytokine levels in crevicular fluid are less responsive to orthodontic force in adults than in juveniles. J Clin Periodontol 29: 757-762, 2002.

27. Sculley DV and Langley-Evans SC: Salivary antioxidants and periodontal disease status. Proc Nutr Soc 61: 137-143, 2002.

28. Palaiologou AA, Yukna RA, Moses R and Lallier TE: Gingival, dermal, and periodontal ligament fibroblasts express different extracellular matrix receptors. J Periodontol 72: 798-807, 2001.

29. Fuchs SY, Adler V, Buschmann T, Wu X and Ronai Z: Mdm2 association with p53 targets its ubiquitination. Oncogene 17: 2543-2547, 1988.

30. Shieh SY, Ikeda M, Taya Y and Prives C: DNA damage-induced phosphorylation of p53 alleviates inhibition by MDM2. Cell 91: 325-334, 1997. 